\title{
Pemanfaatan Limbah Pertanian Dalam Mendukung Pengembangan Kawasan Sapi Potong Di Kecamatan Mapilli Kabupaten Polewali Mandar
}

\author{
Utilization of Agricultural Waste for Development of Beff Cattle Livestock Area \\ in Mapilli Subdistrict, Polewali Mandar Regency
}

Juliawati Rauf ${ }^{*}$, Aminah Hajah Thaha ${ }^{2}$

1Program Studi Peternakan, Fakultas Pertanian Peternakan dan Perikanan, Universitas Muhammadiyah Parepare 2Jurusan Ilmu Peternakan, Fakultas Sains dan Teknologi

Universitas Islam Negeri Alauddin Makassar

* Korespondensi Email: juli_mamuju@yahoo.co.id

\begin{abstract}
ABSTRAK
Kabupaten Polewali Mandar merupakan salah satu daerah jumlah populasi sapi potong tertinggi di Sulawesi Barat. Wilayah ini sangat berpotensi dalam pengembangan ternak sapi potong. Untuk itu, pihak pemerintah di Provinsi Sulawesi Barat melihat potensi lahan yang yang memadai di Kecamatan Mapilli Kabupaten Polewali Mandar untuk pengembangan peternakan sapi potong. Tahap awal yang bisa dilakukan adalah penyediaan pakan untuk keberlangsungan hidup ternak sapi, karena itu hal yang paling pokok dalam pengembangan peternakan khususnya pada ternak sapi adalah ketersediaan pakan hijauan. Namun demikian terkadang ketersediaan pakan berupa hijauan rumput masih sangat terbatas, sehingga dalam pengembangan peternakan sapi dapat diintegrasikan dengan usaha pertanian. Hal ini merupakan salah satu strategi dalam penyediaan pakan ternak melalui optimalisasi pemanfaatan limbah pertanian dan limbah agroindustri pertanian.
\end{abstract}

Kata kunci: Limbah Pertanian, Polewali Mandar, Sapi Potong

\begin{abstract}
Polewali Mandar Regency is one of the highest areas of beef cattle population in West Sulawesi. Beef cattle are very potential to be developed in this region. Therefore, the government of West Sulawesi Province saw the potential in Mapilli District, Polewali Mandar Regency for the development of beef cattle farms.The initial stage is to provide feed for the survival of cattle. Because the most important thing in the development of livestock, especially in cattle is the availability of forage feed. However, sometimes the availability of forage in the form of grass is still very limited. So, the development of cattle farms can be integrated with agricultural businesses. This is one of the strategies in providing animal feed through optimizing the use of agricultural waste and agricultural agro-industrial waste.
\end{abstract}

Keywords : Agricultural Waste, Beef Cattle, Polewali Mandar 


\section{PENDAHULUAN}

Kabupaten Polewali Mandar merupakan salah satu kabupaten yang ada di Provinsi Sulawesi Barat yang berpotensi sebagai penghasil produk peternakan khususnya ternak sapi potong. Dinas Pertanian dan Peternakan (2012) mengemukakan bahwa Kabupaten Polewali Mandar ini merupakan wilayah yang memiliki populasi ternak sapi yang jumlahnya lebih besar dibandingkan dengan kabupaten lain di Sulawesi Barat. Berdasarkan data Badan Pusat Statistik Kabupaten Polewali Mandar (2018) ketahui bahwa total populasi sapi potong di Kabupaten Polewali Mandar pada Tahun 2017 sebesar 31.974 ekor

Sebagai salah satu daerah dengan populasi sapi potong di Sulawesi Barat yang tertinggi, maka pihak pemerintah di Provinsi Sulawesi Barat ini mendorong pemerintah Kabupaten setempat untuk menyiapkan lahan yang cukup luas sebagai sebagai tahap persiapan pengembangan kawasan sapi potong. Salah satu lokasi yang berpotensi di Kabupaten Polewali Mandar adalah Kecamatan Mapilli, selain topografinya dan iklim yang memungkinkan juga kecamatan tersebut memiliki populasi ternak tertinggi Se Kabupaten Polewali Mandar yaitu 6.092 ekor atau sebesar 19,05\% dari total keseluruhan populasi (Hazliansyah, 2018). Salah satu syarat mutlak penyiapan suatu kawasan ternak sapi potong adalah penyiapan lahan hijauan makanan ternak. Dengan demikian Pemerintah Kabupaten Polewali Mandar khususnya Kecamatan Mapilli dapat lebih mudah untuk mengembangkan kawasan tersebut.

Berdasarkan latar belakang yang telah diuraikan diatas, maka rumusan masalahnya adalah bagaimana potensi limbah Pertanian untuk mendukung pengembangan kawasan sapi potong di Kecamatan Mapilli Kabupaten Polewali Mandar. Tujuan dari penelitian ini yaitu mengidentifikasi potensi limbah Pertanian untuk mendukung pengembangan kawasan sapi potong di Kecamatan Mapilli Kabupaten Polewali Mandar. Hasil penelitian ini diharapkan dapat dijadikan sebagai sumber informasi kepada para pengambil kebijakan terkait potensi limbah Pertanian untuk mendukung pengembangan kawasan sapi potong di Kecamatan Mapilli Kabupaten Polewali Mandar

\section{MATERI DAN METODE}

\section{Jenis dan Lokasi Penelitian}

Jenis penelitian ini adalah penelitian kualitatif yang merupakan field research. Lokasi penelitian adalah di Kabupaten Polewali Mandar Provinsi Sulawesi Barat. Penelitian 
ini dilaksanakan di Kabupaten Polewali Mandar Provinsi Sulawesi Barat pada Tahun Bulan Februari - April Tahun 2013.

\section{Sumber dan Metode Pengumpulan Data}

Sumber data dalam penelitian ini diperoleh berdasarkan hasil survey ke Lokasi Penelitian dan Data yang di peroleh dari Dinas Pertanian Kabupaten dan Badan Pusat Statistik Kabupaten Polewali Mandar . Teknik pengambilan sampel dilakukan secara purposive. Metode pengumpulan data terdiri dari survey, observasi, wawancara, dan dokumentasi. Adapun teknik yang dilakukan dengan wawancara tidak terstruktur dan wawancara terstruktur.

\section{HASIL DAN PEMBAHASAN}

\section{Potensi Pengembangan Ternak Sapi Potong di Kecamatan Mapilli Kabupaten Polewali Mandar}

Salah satu wilayah yang memiliki potensi untuk pengembangan peternakan sapi potong di Provinsi Sulawesi Barat adalah Kabupaten Polewali Mandar. Pemerintah Provinsi Sulawesi Barat telah menetapkan prioritas pembangunan, dimana salah satunya adalah pembangunan pertanian dalam arti luas dalam rangka revitalisasi pertanian. Pembangunan peternakan merupakan salah satu bagian dari prioritas tersebut yang pada dasarnya adalah untuk menyediakan pangan asal ternak baik kualitas maupun kuantitas serta turut berperan dalam mendorong terhadap peningkatan kualitas sumberdaya manusia dari sisi pemenuhan gizi melalui penyediaan konsumsi protein hewani asal ternak yaitu daging, telur, dan susu (Dinas Pertanian dan Peternakan, 2011).

Pengembangan sapi potong tidak dapat dipisahkan dari perkembangan usaha pertanian, karena usaha pertanian memiliki potensi ketersediaan limbah pertanian yang dapat dimanfaatkan sebagai pakan untuk pengembangan ternak sapi potong. Berdasarkan data Badan Pusat Statistik (2012) bahwa Kabupaten Polewali Mandar merupakan salah satu daerah penghasil Pertanian di Provinsi Sulawesi Barat. Selain tanaman padi sebagai komoditi Pertanian andalan, Pertanian lainnya yang dihasilkan Kabupaten Polewali Mandar adalah jagung, ubi kayu, ubi jalar, dan kacang-kacangan. Adapun luas areal panen tanaman padi di Kabupaten Polewali Mandar 41.583Ha (Badan Pusat Statistik Kabupaten Polewali Mandar, 2018). Kabupaten Mapilli memiliki luas 4,54\% $\left(91,75 \mathrm{Km}^{2}\right)$ dari total wilayah di Kabupaten Polewali Mandar, pada ketinggian 21 m DPL. 
Berdasarkan hasil survei produksi limbah Pertanian diperoleh bahwa jerami padi memiliki produksi limbah Pertanian tertinggi di Sulawesi Barat khususnya Kabupaten Polewali Mandar. Hal ini disebabkan karena tingginya luas areal panen komoditi tersebut, sehingga jumlah produksi limbahnya lebih banyak (Dinas Pertanian dan Peternakan, 2011).

\section{Ragam dan Ketersediaan Sumber Bahan Pakan Limbah Pertanian}

Salah satu faktor penentu keberhasilan pembangunan peternakan adalah ketersediaan sumberdaya pakan. Namun padang penggembalaan sebagai penyedia pakan hijauan cenderung berkurang setiap tahun. Dilain pihak, terjadinya perubahan fungsi lahan yang sebelumnya sebagai sumber pakan menjadi lahan pertanian untuk memenuhi tuntutan penyediaan pangan akibat meningkatnya jumlah penduduk. Meningkatnya intensifikasi Pertanian mengakibatkan peningkatan produksi limbah Pertanian (Syamsu, 2011).

Syamsu (2011) mengemukakan bahwa sumber limbah pertanian diperoleh dari komoditi Pertanian. Jenis limbah Pertanian yang dapat dimanfaatkan sebagai sumber pakan adalah jerami padi, jerami jagung, jerami kedelai, jerami kacang tanah, pucuk ubi kayu, serta jerami ubi jalar. Untuk mendukung pengembangan ternak sapi potong, maka potensi limbah Pertanian sebagai sumber pakan perlu untuk diketahui.

\section{Pemanfaatan Limbah Pertanian Sebagai Pakan Untuk Ternak Sapi Potong}

Peningkatan produksi ternak khususnya ternak ruminansia dalam hal ini ternak sapi akan berhasil dengan baik, jika ketersediaan pakan dapat dipenuhi secara kualitas dan kuantitas yang tersedia secara kontinyu (Syamsu, 2011).

Pakan utama ternak sapi adalah hijauan yaitu sekitar 60-70\%. Namun demikian karena ketersediaan pakan hijauan sangat terbatas, maka pengembangan peternakan dapat diintegrasikan dengan usaha pertanian sebagai strategi dalam penyediaan pakan ternak melalui optimalisasi pemanfaatan limbah pertanian dan limbah agroindustri pertanian (Maryono dan Romjali, 2007).

Limbah Pertanian memiliki potensi yang cukup besar sebagai makanan ternak. Karakteristik limbah Pertanian secara umum kualitas nutrisi yang rendah dengan tingginya kandungan serat kasar dan rendahnya kandungan nitrogen, kalsium serta fosfor mengakibatkan daya cerna limbah Pertanian dan konsumsi menjadi terbatas, namun masih berpotensi digunakan sebagai sumber energi. Salah satu upaya meningkatkan nilai manfaat limbah Pertanian sebagai pakan telah dilaporkan beberapa peneliti contohnya dengan 
penambahan urea $4 \%$ pada jerami padi, fermentasi dengan starter mikroba starbio sebelum pemberian pada ternak (Dinas Pertanian dan Peternakan, 2011).

Peningkatan nilai nutrisi daun ubi kayu dengan teknologi silase menunjukkan bahwa dengan penggunaan aditif cairan limbah industri sirup dapat menurunkan $\mathrm{pH}$ silase dari awal fermentasi $(\mathrm{pH} \mathrm{6,10)}$ dan setelah difermentasi selama 14 hari menjadi 3,73. Dengan demikian silase daun ubi kayu dapat disimpan untuk digunakan sebagai pakan ternak. Dilain pihak, penggunaan hay daun ubi kayu dengan ransum basal jerami padi dapat meningkatkan konsumsi dan kecernaan pakan pada ternak sapi (Dinas Pertanian dan Peternakan, 2011).

\section{Potensi Limbah Pertanian Sebagai Sumber Pakan Ternak Sapi Potong di Kabupaten Polewali Mandar}

Berdasarkan data hasil kajian dari Dinas Pertanian dan Peternakan (2011) dari hasil survey produksi masing-masing limbah Pertanian diperoleh rata-rata produksi segar, produksi kering dan produksi bahan kering dari masing-masing limbah Pertanian seperti yang terlihat pada Tabel 1.

Berdasarkan Tabel 1. menunjukkan bahwa rata-rata produksi segar, produksi kering dan produksi bahan kering dari tiap-tiap Pertanian yang diusahakan adalah tanaman padi menghasilkan limbah Pertanian dengan produksi segar (12 ton/ha), produksi kering $(6,77$ ton/ha), dan produksi bahan kering (5,88 ton/ha) yang cukup tinggi bila dibandingkan dengan limbah Pertanian lainnya dan disetiap kecamatan mengusahakan tanaman padi sebagai usaha pokok dan merupakan makanan pokok masyarakat di Kabupaten Polewali Mandar. Hal ini sesuai dengan data dari Dinas Pertanian dan Peternakan (2011) yakni jerami padi merupakan komoditi Pertanian dengan produksi limbah terbesar. Produksi itu sebagian besar berasal dari daerah yang masuk kategori IKP tinggi yaitu Kabupaten Polewali Mandar.

Adapun rata-rata kualitas limbah Pertanian berdasarkan hasil laporan dari Dinas Pertanian dan Peternakan Provinsi Sulawesi Barat (2011) mengemukakan bahwa dari proses analisis proksimat masing-masing limbah Pertanian diketahui rata-rata kualitas limbah Pertanian seperti yang terlihat pada Tabel 1. 
Tabel 1. Rata-Rata Produksi Segar, Produksi Kering dan Produksi Bahan Kering Limbah Pertanian

\begin{tabular}{lrcc}
\hline \multirow{2}{*}{ Limbah Pertanian } & \multicolumn{3}{c}{ Rata-Rata Produksi Limbah Pertanian (Ton/Ha) } \\
\cline { 2 - 4 } & Produksi Segar & Produksi Kering & $\begin{array}{c}\text { Produksi Bahan } \\
\text { Kering }\end{array}$ \\
\hline Jerami padi & 12,00 & 6,77 & 5,88 \\
Jerami jagung & 9,40 & 6,82 & 5,86 \\
Pucuk ubi kayu & 3,50 & 2,16 & 1,83 \\
Jerami ubi jalar & 10,50 & 6,15 & 5,03 \\
Jerami kacang tanah & 8,88 & 5,70 & 4,96 \\
Jerami kacang kedelai & 4,10 & 3,11 & 2,68 \\
Jerami kacang hijau & 10,10 & 6,65 & 5,80 \\
\hline
\end{tabular}

Sumber : Dinas Pertanian dan Peternakan, 2011a

Tabel 1. Terlihat bahwa kandungan protein yang tertinggi adalah pucuk ubi kayu sebesar 18,32\% dan yang terendah adalah jerami padi 5,08\% . Untuk protein kasar masing masing limbah Pertanian tergolong tinggi yakni rata-rata diatas 30\%, dimana kandungan serat kasar yang tertinggi adalah Jerami kacang hijau dan jerami padi yakni sebesar 32,68\% dan $32,53 \%$, sedangkan yang terendah adalah pucuk ubi kayu 21,98\%. Hal ini sesuai dengan hasil penelitian dari syamsu (2006) yang terlihat bahwa kandungan serat kasar Pertanian yang tertinggi pada jerami padi yaitu 33,79\% dan yang terendah pucuk ubi kayu yaitu $21,11 \%$. Begitu pula pada kandungan protein yaitu yang terendah pada jerami padi dan yang tertinggi pada pucuk ubi kayu.

\section{KESIMPULAN}

Faktor yang paling penting untuk diperhatikan dalam pengembangan peternakan khususnya pada ternak sapi adalah ketersediaan pakan hijauan. Namun demikian terkadang ketersediaan pakan berupa hijauan rumput masih sangat terbatas. Sehingga dalam pengembangan peternakan sapi dapat diintegrasikan dengan usaha pertanian. Hal ini merupakan salah satu strategi dalam penyediaan pakan ternak melalui optimalisasi pemanfaatan limbah pertanian dan limbah agroindustri pertanian. Untuk pemanfaatan limbah Pertanian sebagai sumber pakan ternak sapi potong, maka wilayah yang memiliki 
produksi limbah Pertanian yang tinggi sebaiknya dilakukan penyediaan tempat penyimpanan dan sarana penunjang penerapan teknologi pakan.

\section{DAFTAR PUSTAKA}

Badan Pusat Statistik Kabupaten Polewali Mandar. 2012. Data Statistik Polewali Mandar Dalam Angka 2012. Polewali: Badan Pusat Statistik Kabupaten Polewali Mandar.

Badan Pusat Statistik Kabupaten Polewali Mandar. 2018. Kabupaten Polewali Mandar dalam Angka 2018. BPS Kabupaten Polewali Mandar. Auliyah Polewali, Polewali.

Dinas Pertanian dan Peternakan. 2011. Analisis Potensi Sumber Daya Pakan Lokal Limbah Pertanian Untuk Mendukung Pengembangan Sapi Potong di Provinsi Sulawesi Barat. Mamuju: Dinas Pertanian dan Peternakan Provinsi Sulawesi Barat.

Dinas Pertanian dan Peternakan. 2012. Data Statistik Peternakan. Mamuju: Dinas Pertanian dan Peternakan Provinsi Sulawesi Barat.

Hazliansyah. 2018. Sulbar Siapkan Lahan 2.000 Hektar Untuk Peternakan Sapi. (Online), (www.republika.co.id/berita/ekonomi/pertanian/18/03/24/p63p2d280-sulbarsiapkan-lahan-2000-hektare-untuk-peternakan-sapi, diakses Tanggal 11 September 2018).

Maryono dan Romjali, E. 2007. Petunjuk Teknis Teknologi Inovasi Pakan Murah Untuk Usaha Pembibitan Sapi Potong. PT. Remaja Rosdakarya, Bandung.

Syamsu, J.A. 2011. Reposisi Paradigma Pengembangan Peternakan Pemikiran, Gagasan dan Pencerahan Publik. Absolut Media, Yogyakarta. 